Ankara Üniversitesi

SBF Dergisi,

Cilt 73, No. 2, 2018, s. 643 - 666

\title{
ENTREPRENEURIAL MINDSET IN VIDEO GAMING SECTOR: EVIDENGE FROM TURKEY
}

\author{
Dr. Öğr. Üye. Emek Barış Kepenek \\ Başkent Üniversitesi \\ Fen Edebiyat Fakültesi \\ ORCID: 0000-0002-0086-4867
}

\begin{abstract}
Video gaming is one of the fastest growing sectors in the global market. The international games market will reach USD $\$ 110$ billion by 2017 . Although the economic scale of video gaming is continually increasing in Turkey, the country has few gaming companies. Turkey has the ability to be a competitive player in the global video gaming market; however it faces a number of challenges. This article analyzes the current status of the Turkish video gaming sector, including examining its inherent problems and proposing some solutions. The findings are based on a national survey conducted in 2012. Turkey has a large youth population, presenting a good market for gaming companies. The paper finds that there is an urgent need to develop an entrepreneurial ecosystem within Turkey. Pre-incubation centers would play a central role in such developments.
\end{abstract}

Keywords: Video Game, Culture, Incubation, Entrepreneurship, Ecosystem

\section{Video Oyun Sektöründe Girişimcilik: Türkiye Örneği}

\section{Öz}

Video Oyunlar sektörü global pazarlarda en hızlı büyüyen sektörlerden bir tanesi. 2017 yılında büyüklüğün 110 milyar doları geçeceği tahmin edilmektedir. Her ne kadar sektör Türkiye'de de büyümekteyse de, faaliyetteki firma sayısı oldukça azdır. Yapısı gereği rekabetçi bir ülke olabileceken, Türkiye birçok farklı sorunla karșı karşıya kalmaktadır. Bu makale Türkiye'deki video oyun sektörünün yapısı, problemlerini inceleyerek çözüm önerileri geliştirmektedir. Makalede kullanılan çıktılar 2012 yılında ulusal çapta yapılan bir pazar araştırmasından elde edilmiştir. Türkiye'nin sektöre yönelik girdi sağlayabilecek çok büyük genç nüfus potansiyeli vardır. Ancak bu potansiyelin kullanılabilmesi için girişimcilik faaliyetlerine özel önem verilmesi gerekmektedir. Ön kuluçka merkezleri bu bağlamda ön plana çıkmaktadır.

Anahtar Sözcükler: Dijital Oyun, Kültür, Kuluçka, Girişimcilik, Ekosistem

* Makale geliş tarihi: 24.06.2016

Makale kabul tarihi: 23.01.2017 


\section{Entrepreneurial Mindset in Video Gaming Sector Evidence From Turkey}

\section{Introduction}

Video games are extremely valuable commodities in the entertainment industry. The revolutionary changes in digital technologies, and the introduction of the internet, have made video gaming a powerful global industry. The scope of video games now extends beyond its entertainment content (www.esa.org), and is also a medium for companies to interact with their customers and their employees, or for schools to improve educational quality. In the United States (US), the annual video gaming revenues have surpassed the annual Hollywood movie revenues (Brightman, 2008). While the video gaming industry is relatively new ${ }^{1}$, particularly in relation to the movie industry, its socio-economic growth is exceptional. It is currently one of the fastest growing industries globally. In 2017, the global scale of the video gaming industry is expected to surpass USD $\$ 86$ billion (www.newzoo.com).

In contrast, the Turkish video gaming industry is in its infancy. The first two games developed for the market was Keloglan (1989) and Hançer in 1992 (Yılmaz and Çağıltay, 2005). As of 2015, there are almost 50 gaming development studios in Turkey, representing approximately $5 \%$ of the global sector at \$464 million (Tüdof, 2012). This article aims to investigate the status of the Turkish gaming industry, and to develop policy ideas to stimulate the growth of that industry.

To fulfill this aim, a national research project was conducted ${ }^{2}$. The study used two research methods: a strengths, weaknesses, opportunities, and threats (SWOT) analysis, and a questionnaire survey. First, a group of industry stakeholders were invited to undertake a detailed SWOT analysis which

1 Although there are some older samples, the first commercial game was Galaxy Game in 1971 (Zackariasson and Wilson, 2012).

2 The research project was managed by the author of this article and was supported by the Animation Technologies and Game Development Center (located in the Middle East Technical University (METU) Technopark) and the Ankara Development Agency. 
provided a clear outline of the structure (problems and advantages) of the Turkish gaming sector. Then, the managers of 25 Turkish video gaming companies were interviewed to evaluate the SWOT analysis. The findings were shared with academics and industry experts. Finally, several policy suggestions were developed to tackle the problems in the gaming sector.

Approximately half of the surveyed video gaming companies are microenterprises, employing fewer than 10 people. Moreover, many are newly established, with $45 \%$ of the surveyed companies in existence for less than three years. All of the surveyed companies are start-ups, and all of the owners are entrepreneurs. The main problems facing these companies are the shortage of a skilled workforce, the lack of state incentives, and providing channels for marketing.

The entrepreneurial mindset is a crucial factor for improving the gaming sector. Hence, the sector needs regulated entrepreneurial initiatives and dedicated supports. Correspondingly, a pre-incubation process is a powerful tool for developing the gaming industry. In pre-incubation centers, young entrepreneurs who lack industrial experience (both financial and managerial) are supported before establishing their startup companies. Those centers provide support through initiatives such as training, networking, and mentorship (Peters, Rice and Sundararajan, 2004; Grimaldi and Grandi, 2005; Bergek and Norrman, 2008). Besides, it is known that the intervention of such agents provides fostering market or non-market interactions to create, produce and sell the sectoral products. This will definitely stimulate the success of the sector as a whole (Malerba, 2002; Howells, 2006; Sapsed et. al, 2007)

Section two of the article discusses the video gaming industry in general. The industry is analyzed economically to understand why video gaming is such an important economic sector. Section three analyses the video gaming industry in Turkey. Section four contains policy suggestions for developing the video gaming industry in Turkey. The proposals may initiate further debates on creating a working model for developing countries.

\section{A Game is not Just a Game: It is a Commodity}

Games, in general, are as old as humanity (Huizinga, 2013). They infiltrate our daily lives in many different forms, and today are played everywhere including in the streets, in schools, on the television, on personal computers (PCs), and on smartphones. Games are entertainment, allowing us to escape from daily stresses, to search for new challenges, or to find new sources of joy and excitement. Video games, in particular, are a powerful tool that offers different opportunities for people because of technological and innovative advancements (O'Donnell, 2012; Ashton, 2011). It is possible to 
play short video games on a mobile telephone or to deeply enter into a fantasy world in a PC-based game. Video games can also be played on a dedicated gaming console. Different gaming platforms offer different types of content and services; but why? The answer is simple: a game is not just a game, it is now a commodity. Developing a video game is a business (Edery and Mollick, 2009). All of the video gaming platforms (consoles, PCs, smartphones) are developed for economic reasons; and the video gaming industry is extremely valuable. The vast socio-economic world behind video games is more complex than Blizzard Entertainment's World of Warcraft game. Video gaming is also called digital gaming ${ }^{3}$, because the gaming platforms are the result of the global digital revolution.

People love games and enjoy playing games when they can. From the enjoyment perspective, there is little difference between video games and traditional games. The main difference is that video games offer attractive, intense, and profound content via technology and new media (Binark and Bayraktutan, 2008). There are many different types of video games, and not all provide the same benefits. For example, the game company Big Fish produced 250 games in 2013, and offers fourteen different genres of games (Netzley, 2015; Bigfish, 2014). Big Fish specializes in casual games that have relatively simple rules and short gameplay times. The gamer can play, for example, while waiting in a queue, during a work break, or on a bus journey. It is possible to purchase a game for a smartphone, and to consume the product in 2 hours... and to then buy a new game. While purchasing and consuming a game is easy, the development of that product is more difficult. Generally, video games have an economic value dependent on the services offered. They are inarguably an economic commodity.

There is no standard service for a video game; it is possible to play the same game via PC, tablet, smartphone, or television. That is, games can be provided in a different manner depending on their storyline and content. However, the first step in the playing process is to buy the game. A video game can be purchased without touching a physical version. The virtual landscape means that the consumer does not have to be in the same physical place as the desired product.

\subsection{It is not Just About Game Development!}

Game development is not just related to software development: the video game industry is not the software industry. The gaming industry contains broad

3 This article uses the terms video gaming and video games. 
social, cultural, technological, and political-economic systems within which the world of game development is rooted. The video game industry has many economic aspects, including the development process, employment, the release period, advertising, marketing, and intellectual property (IP) rights (Edery and Mollick, 2009).

Different gaming platforms offer different features for different tastes, with the developers exploiting the possibilities offered by new technology. Several main platforms have emerged (http://www.ecchigames.com/videogame-platforms.html; Wolf, 2012), as outlined below.

Arcade games: Arcade games were the first video gaming platforms. Such games are generally coin-operated, and tend to be located in arcades, bars, hotels, and similar business establishments. Arcade games are commonly styled in upright cabinets, with their control panels located below a viewing screen. Arcade games allow players to play individually, to take turns, or to go head-tohead in a variety of different games. Arcade game examples include Street Fighter, Pacman, and Pinball.

Console games: The console platform was produced specifically for the gaming industry. Unlike PC gaming, console-based gaming requires a separate gaming unit (console), and the use of a dedicated device that displays the console's output through an external monitor, typically a television screen. Today, there are three main console producers: Microsoft Xbox, Sony PlayStation, and Nintendo Wii.

Handheld video games: Handheld video game platforms are similar to the standard consoles; however, the device is portable and the screen is an integrated part of the device. Milton Bradley's MicroVision was the first handheld system to use removable cartridges and was released in 1979. Subsequently, and until the 2000s, Nintendo's Gameboy (later replaced by the Nintendo DS) was the market leader for this platform type (Wolf, 2012). In the 2000s, Sony entered the market with its PlayStation Portable (PSP). With the advent of smartphones, the market share for handheld platforms decreased sharply. Sony had stopped producing PSP devices by 2014 (http://www.theguardian.com/technology/2014/jun/04/sony-psp-handheldnintendo).

Massively Multiplayer Online Games (MMOGs): A massively multiplayer online role-playing game (MMORPG) is a type of video game that is played with many other players simultaneously in an online persistent game world, where a player assumes the role of a fictional character. This is a platform that is actually owned and operated by a company; for example, Blizzard Entertainment's World of Warcraft. 
Mobile games: Mobile games have arisen with the popularity of sophisticated 'smart' phones that have a huge number of features, among them the ability to play games. These games are very low in price (some are free), and can be downloaded to a mobile phone. Technology developments have resulted in smart mobile phones, with multipurpose features. Mobile games can move more freely from the screen of one device to that of another, giving them their title.

Online games: The online game platform differs from the MMOG platform in that it does not generally include a persistent world. Online games are video games that can be found and played on networked computers, or computing devices, and on the Internet, including its graphical interface, the World Wide Web.

PC games: In the 1980s, computers became personalized. Although there are now many different gaming platforms, the PCs is still one of the most powerful ways to play video games. PCs can handle a broad range of game types, making this platform a strong choice for many gamers today.

A video game can be developed for whatever platform the developer chooses. The decision depends on the developer's personal ambitions, and the capability of the game studio (Zackariasson and Wilson, 2012).

\subsubsection{Video Game Development: Process}

Regardless of the platform, all video games follow a similar process; from the development to marketing stages (Dyer-Witheford and Sharman, 2005). The gaming sector has a complex value chain. Constant innovation means that the video game industry tends not to have a typical value chain. A concurrent engineering approach to developing products is used, allowing new games to be created quickly. Figure 1 shows the video gaming value chain (Shah, 2005; Langlotz, Rhode, and Whaley, 2008; McCoy, 2010; Helppi, 2015). Game studios deal mainly in the first three stages of the value chain.

Figure 1: The video games industry value chain

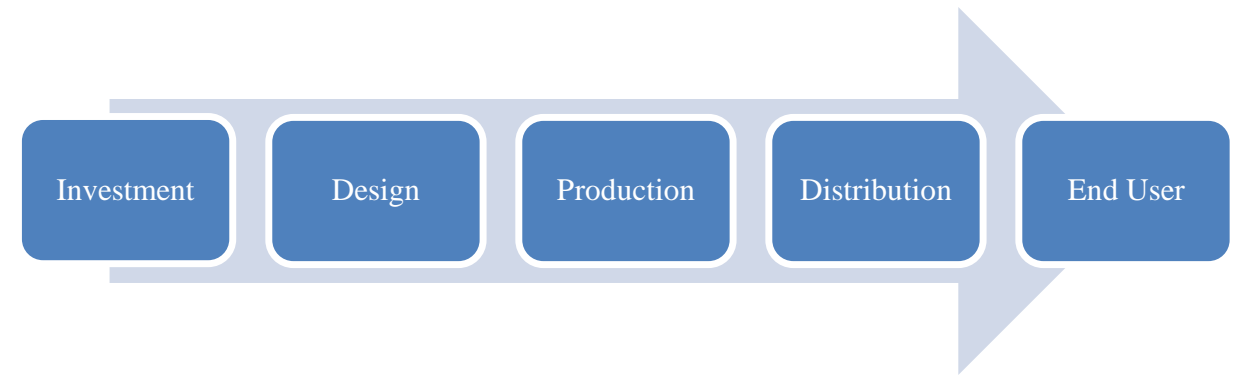


Investment: Investment comprises the first stage in the value chain of the video games industry. Adequate investment is needed to develop and produce video games.

Design: The design stage requires specialized skills, and includes inputs from designers, developers, and artists. It is also called the pre-production stage. The overall story of the game is designed at the stage, as are the various game levels.

Production: This stage encompasses the entire production process, and includes the game engine and the middleware. The engine and the technology types used depend on the game platform. During production, the project managers must resolve any timing or planning problems. At the end of the production process, the testing stage is initiated.

Distribution: The developed game must be sold through marketing channels to earn money. Specialist marketers are required for the distribution stage. Distribution can be online or through retailers. Some companies (such as Square Enix and Electronic Arts) both develop and distribute games.

End User: The end users are all of the gamers who purchase and play games. Their preferences determine the growth path of the industry.

In terms of development, there are also three main stages (Walfisz, Zackariasson and Wilson, 2006; Jethva, 2015) as follow.

Pre-production: The pre-production stage includes the concept development and the design processes. A detailed design plan is generated for the potential game. The game type and the platform to be used are decided at this stage. The producer and the project manager coordinate all of the teams involved in the pre-production process, and plan the scheduled timing for each task. An active pre-production stage means that creativity (that results in an immersive and fun game) is built into the development process, and thereby built into the project (Zackariasson and Wilson, 2012).

Production: Production is the most important stage of the development process. This stage covers the implementation process and involves the cooperation of artists, programmers, and technical directors. Production is the most difficult, and the most expensive, stage of the game development process.

Post-production: The post-production stage involves testing and deployment of the new game. Once the game is developed, testers must play the game to find any bugs that it contains. Beta testing and marketing strategies are also determined in the post-production stage. 


\subsubsection{Video Game Development: People}

The video game industry participants include the developers, publishers, distributors, retailers, customers, consumers, IP-owners, platform owners, and hardware owners. Game development is a creative and collaborative process involving numerous disciplines; it is rooted in a particular culture producing creative, artistic, and culturally important works (Zackarisson and Wilson, 2012).

A variety of skills are needed to produce a single product, meaning that developing a game is not easy. A single game requires the involvement of numerous people from different disciplines including: game design, visual design, programming, modeling, game-level design, testing, and marketing. However, the developer is the main actor in the process. Notably, different actors work together as one to present a coherent and an immersive gaming experience for the consumer (Zackarisson and Wilson, 2012).

\subsubsection{Video Game Development: Publishers}

Readman and Grantham (2006) suggest that the video game value chain has changed in the last twenty years, to one that is publisher-centric. However, the people mentioned in Section 2.1.2 could be described as forming the core of the video game value chain - from developer to consumer-where each actor contributes, and adds value, to the video game.

Saying that, the game developers generally lack the financial capabilities to fund and promote their games; hence, the publishers are essential participants in bringing games to the market. The publishers work with different developers (third party, in-house, and independent) to build portfolios of games. While doing this, the publishers also try to adapt the game development to the current market trends, and attempt to establish promotion strategies.

Publishers are the industry actors who tend to take the financial risks in video game development. The budget for an AAA game (a high-quality game, with an expected high sales volume) is estimated at \$15-\$20 million for most games. Microsoft spends an estimated $\$ 30$ million developing each game. The budgets for AAA titles seem to be on the increase, depending on the technical platform and the genre. In addition to the development costs, there are also marketing and sales costs. Microsoft reportedly spent approximately $\$ 40$ million on the marketing and sales of Halo 3 (Zackarisson and Wilson, 2012). 


\subsubsection{Video Game Development: Marketing and Distributing}

Those interested in entering the gaming industry should be aware that each game has not only its own story and development process, but also its own marketing strategy. Selling a game is not like selling a product in Apple's AppStore or in Google's Play Store. Video games have a developer-distributor model, where the games are sold to an end user via the distributors. For example, for PC-based games, the consumer can visit a physical store to investigate the product, or they can use a virtual distributor (such as Steam). Each purchasing type requires a different marketing strategy (ODTÜ Teknokent, 2012).

\section{Video Game Market}

Generally, video games are not chance purchases. Each year, millions of people around the world deliberately pay for and play video games. The increasing number of games sold means increasing levels of money (EgenfeldtNielsen, Smith, and Tosca, 2008). Video games are closely related to the economy and the media. Games are very much influenced by 'culture', and are the products of cultural industries (Kerr, 2006; Binark and Sütçü, 2008; Dymek, 2010). National culture, geek culture, gamer culture, anime culture, and numerous other cultural aspects impact on game development and on gaming studios alike. In other words, cultural aspects infuse the very design of a game (O’Donnell, 2012).

The concept of culture industries was introduced by Adorno (2004). He considers that a culture industry is operated according to a plan that aims at increasing mass consumption using technological, economic, and cultural ingredients (Adorno, 2004). A culture industry works independently of the prevailing political and economic system, rather than being a fundamental part of it (Kerr, 2006). The dissemination opportunities offered through new media means that capitalists can target all aspects of social and cultural meanings. Hesmondhalgh (2007) states that video games are niche aspects of culture industries, because their planning, production, and marketing are all capitalistic: in the end, they create profit.

Video games are a daily consumption product, played by people of all ages. The type of game played, and the platform used to play it, are determined by the time allotted by the player for playing the game, by the meaning of the game, and by the budget limitations. The video game industry makes money by selling the product directly to consumers (either through retail outlets, by downloads, or through websites such as Steam), and by subscription fees for 
online games. However, like other culture industry products, video game marketing is supported by intense advertisement and through trade fairs (Binark and Sütçü, 2008).

\subsection{Global Video Game Market}

The video game market is growing fast. In its 2014 Global Games Market Report, the games market research company Newzoo projects that the international games market will reach almost $\$ 103$ billion by 2017 (see Figure 2 ). This represents a compound annual growth rate (CAGR) of $+8.1 \%$. This is due to the tremendous growth of both the Asian markets and mobile gaming (https://newzoo.com/insights/articles/global-games-market-will-reach-102-9billion-2017-2/). The annual global game sales have surpassed the annual global movie box office sales for a number of years. However, video games are now a serious competitor to the entire TV/film industry, with gameplay now eating into mainstays such as television viewing (Egenfeldt-Nielsen, Smith, and Tosca, 2008).

Figure 2: Global video games sales (billion USD)

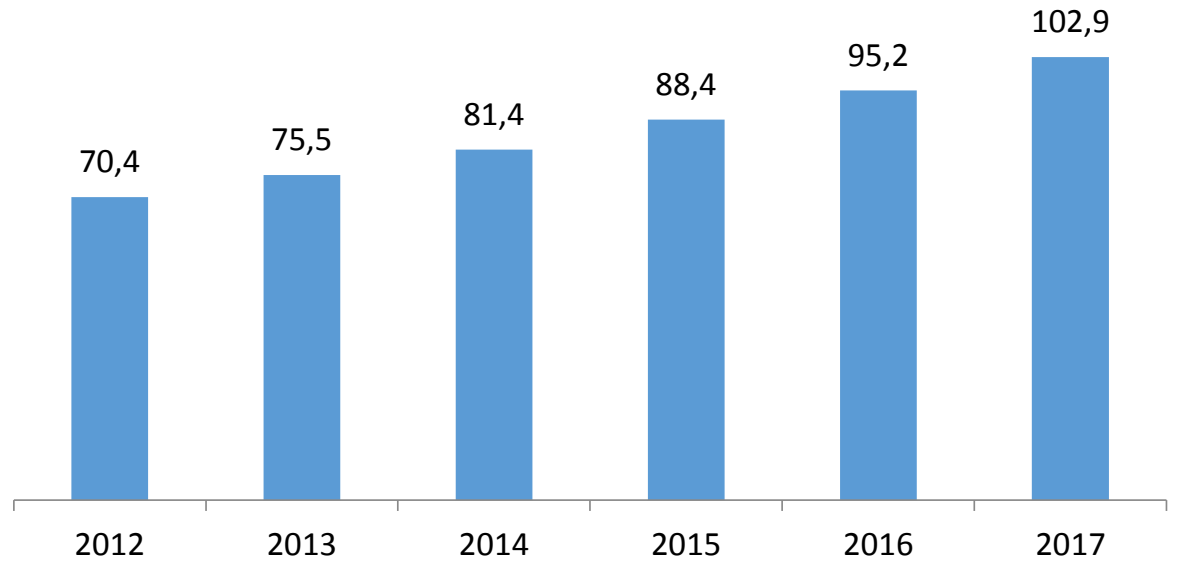

Source: http://www.newzoo.com

The total sales figures hide interesting dynamics in the different subsectors of the video gaming industry. Each gaming platform has its own trends; for example, mobile gaming is increasing. The market for (smart) phones and tablets is projected to increase from $\$ 17.6$ billion (a total gaming market share of 23\%) in 2013, to $\$ 30.7$ billion in 2016 (a total gaming market 
share of approximately 32\%) and to $\$ 35.4$ in $2017 \mathrm{https} / /$ newzoo.com/ insights/articles/global-games-market-will-reach-102-9-billion-2017-2/.

Despite the rising trend in mobile game development, the market shares of consoles and of portable consoles has decreased. In 2010, consoles accounted for approximately $66 \%$ of the video game industry value (Gartner, 2011). This fell to $31 \%$ in 2014, and is estimated to fall to $24 \%$ in 2017 (CGA, 2014).

Newzoo statistics show that not all regions demonstrate the same affinity with games (See Table 1). For example, Asian and Pacific countries have approximately one billion gamers, a total revenue of $\$ 43.1$ billion in 2014 , and an annual growth rate of $14.7 \%$ (the annual average spend per customer is \$43.10). Contrastingly, in Latin America there are approximately 189 million gamers, yet the total revenue is only $\$ 4$ billion (annual average spend per customer \$21.16). In North America and Canada, there are 208 million gamers who spent 23.8 billion for games (annual average spend per customer \$114.42). Eastern Europe and Europe have approximately 335 million gamers, with revenues of $\$ 18$ billion (annual average spend per customer $\$ 53.73$ ). Finally, in the Middle East (including Turkey), there are 251 million gamers, with a total revenue of \$2.1 billion (annual average spend per customer \$8.37) (www.newzoo.com).

Table 1: Game revenues by regions

\begin{tabular}{lccc}
\hline \multicolumn{1}{c}{ Region } & $\begin{array}{c}\text { Gamer } \\
\text { numbers } \\
\text { (million) }\end{array}$ & $\begin{array}{c}\text { Annual gaming } \\
\text { revenue } \\
\text { (million USD) }\end{array}$ & $\begin{array}{c}\text { Annual average } \\
\text { spend per gamer } \\
\text { (USD) }\end{array}$ \\
\hline United States and Canada & 208 & 23800 & 114.42 \\
Europe and East Europe & 335 & 18000 & 53.73 \\
Asia Pacific & 1000 & 43100 & 43.10 \\
Latin America & 189 & 4000 & 21.16 \\
Middle East (including Turkey) & 251 & 2100 & 8.37 \\
\hline
\end{tabular}

Source: www.newzoo.com and author's own calculations 4

AAA games are particularly economically valuable. For example, the sales revenue of Grand Theft Auto V, developed by Rockstar North, exceeded

4 The last column is explored by the author in order to improve the quality and the profoundness of the table. The results were simply obtained by dividing Column 2 to Column 1. 
$\$ 1$ billion in the first three days of its launch. While it cost approximately $\$ 265$ million to develop the game, over 32.5 million copies were sold (www.gamasutra.com).

It is unclear how the gaming market will develop in the future; however, some trends are apparent. The gaming market is clearly moving from physical to digital platforms (Zackariasson and Wilson, 2012). Accordingly, both the publishers and the retailers are adjusting their strategies to stay relevant to their consumers and to capitalize on the market's momentum. Other segments are emerging that offer alternative business models and new types of games, and these segments are attracting new types of gamers. While sales statistics provide an information feedback loop to the industry, demand is extremely uncertain. Most of the video games titles that are released do not make a profit. However, it is clear that video games will be the biggest and the most valuable sector of the entertainment industry for the foreseeable future.

\subsection{Turkish Video Game Market}

The Turkish video games industry experienced a $27 \%$ growth in current value terms in 2014. This growth was mainly because of the rapid increase in the popularity and use of digital games stores, such as Steam and Play Store (http://www.euromonitor.com/video-games-in-turkey/report). These stores offer a centralized location for purchasing video games. In Turkey, PC and console game downloads grew by $59 \%$ in 2014 . Additionally, the ongoing rise in the gaming population also drove the current value growth, along with the decreasing share of pirated software (http://www.euromonitor.com/videogames-in-turkey/report).

Similar to the global situation, the Turkish video gaming industry currently has an upward economic trend. The number of gaming companies, and the scale of the market are both growing exponentially. Turkey's 22 million gamers represent $2.3 \%$ of the global gaming industry. The market size has just surpassed \$200 million (www.newzoo.com; Tüdof, 2012). Overall, the video gaming industry in Turkey has significant growth potential.

Turkey's 78 million population (2015 figure) are relatively high users of social and mobile platforms. As of 2015 , approximately $45 \%$ of the Turkish population had an internet connection, and 36 million people actively used Facebook. On average, each day Turkish people spend 4.9 hours on computers, and 1.9 hours on mobile devices. Each user spends approximately 2.32 hours on social media each day. The most used social media interfaces are Facebook (93\%), Twitter (72\%), Google+ (70\%) and LinkedIn (33\%) (www.wearesocial.sg). 
Video games are expected to see a strong constant 2014 value compound annual growth rate (CAGR) until 2020. The use of digital gaming platforms is expected to become much more widespread in Turkey, and smartphone and tablet ownership is also likely to increase. Consequently, it is predicted that PC and console game downloads and mobile games will register constant 2014 value CAGRs of $18 \%$ and $12 \%$, respectively. This means that these categories will be key drivers of growth in the Turkish video game industry for the coming years (http://www.euromonitor.com/video-games-in-turkey/report).

\subsubsection{Market Analysis of the Turkish Gaming Industry}

A market analysis of the Turkish gaming industry was undertaken in 2012. The analysis aimed to clarify the problems that exist in the sector, and to establish policy ideas to resolve such problems.

\subsubsection{Methodology}

This article is based on field research undertaken in 2012. Before the field study, a SWOT analysis was undertaken. The SWOT technique is generally used for a product, a service, or a market when deciding on the best way to produce, to provide, or to research the relevant thing in the future. A SWOT analysis was used in this case, to determine the type and the content of the market survey questionnaire. The strengths and the weaknesses that were identified were the internal factors over which there was some measure of control. The opportunities and the threats that were identified, were the external factors over which there was no control (Team FME, 2013).

Approximately 45 representatives from different fields (including academics, managers, marketing directors, designers, and journalists) in the Turkish gaming sector participated in the SWOT analysis in April 2012, Ankara. A random sampling method was used to define the participants. The crucial point for sampling was the diversification of the stakeholders who represented different fields of the gaming sector.

The main subject of the analysis was determined as the video gaming sector in Turkey. The participants were asked to evaluate the sector according to both its internal (strengths and weaknesses) and its external (opportunities and threats) features. For the internal features, the participants discussed aspects such as the capacity of the system, its advantages and disadvantages, and the expectations of the stakeholders. For the external features, the participants discussed aspects such as the parameters of the national sector, and the international sector. The participants were divided into four groups. In the end, the participants determined 23 strengths, 30 weaknesses, 11 opportunities and ten threats in relation to the Turkish gaming industry. 
A survey of the Turkish gaming companies was then undertaken as the second aspect of the research. The survey questions arose from the SWOT results. There are few gaming companies in Turkey, and only the companies that had developed games or services were included in the study. Overall, 25 of the $28^{5}$ eligible identified companies participated in the survey, an $89 \%$ response rate. Although there is no clear database on the number of gaming companies in Turkey, the survey used a snowball sampling method to identify the respondents. Snowball sampling is a non-probability sampling technique where existing subjects recruit further subjects from among their acquaintances. As the sample builds up, enough data are gathered to be useful for research. This sampling technique is often used in hidden populations that are difficult for researchers to access (Neuman, 2006).

The field study used a semi-structured survey method. This method allows the deep investigation of a subject through face-to-face interaction (Bailey, 1994). The semi-structured interview is valuable because it makes the respondent comfortable during the interview, facilitating the collection of: personal information, feelings, and ideas, tacit knowledge, direct feedback on the subject, and new questions on the subject (Bailey, 1994; Neuman, 2006). All of the interviews were undertaken by a single researcher in May-June 2012. The interviews were undertaken in both Ankara and İstanbul.

The survey questionnaire aimed at gathering ideas from the Turkish gaming companies on their development processes, their innovations, and their research and development (R\&D) implementations, and also on the collaborations within the sector. The questionnaire also addressed the problems within the sector in Turkey.

The questionnaire had four main parts. The first part consisted of general questions about the company (the number and profile of workers); the work force problems; the training activities; and the competitiveness in the gaming sector. The second part investigated the partnerships within the sector, and the process and product innovative activities of the companies. The third part was to establish the level of technological awareness of the companies and of their employees. The final section addressed the gaming sector problems in Turkey and the possible solutions.

\subsubsection{It is not Easy to Pass This Level! Findings}

This section discusses the findings of the ODTÜ Teknokent report (2012). This report is the most comprehensive research on the Turkish gaming sector to date.

5 On the date of survey, only 28 gaming companies were identified. 
The Turkish video gaming industry is relatively new ${ }^{6}$. Indeed, $90 \%$ of the startups were established after 2000, and $45 \%$ were established after 2010. The average age of a Turkish gaming company is 2.2 years. It can be difficult to develop an industry that uses technology intensely, because the absorption of a new game by the gamers takes a long time. Enculturation (the development of more games, and an increase in gamer numbers) is needed to develop the industry. Realistically, the Turkish gaming industry is in its infancy.

All of the gaming companies in Turkey have an entrepreneurial background. Most Turkish gaming companies are established by gamers who decide to develop their own games. The majority of the companies are microsized enterprises, with $48 \%$ (12 companies) employing fewer than 10 people. Only three of the enterprises employ over 50 people.

As mentioned in the value chain discussion and also in SWOT, investment is critical for the development process. Unfortunately, there is no adequate investment climate in the Turkish video gaming sector. Only two of the 25 surveyed firms received investment capital. Most of Turkey's gaming companies have a domestic co-founder. There is no foreign direct investment in Turkish gaming entrepreneurs; this is because the Turkish gaming sector is in its infancy. This why the competitive level of Turkish sector remains low if compared with the globe.

In relation to employees: $14 \%$ of all employees have managerial duties, $80 \%$ work in the production process, and $6 \%$ work at the administrative level. Interestingly, in common with many micro- and small-enterprises, all of the managerial employees also work in the production process. Turkish gaming companies tend not to have a formal organizational structure, because of the lack of a skilled workforce for both management and production, and because the sector is relatively underdeveloped.

Of the companies surveyed, 90\% (22 companies) have difficulties finding a skilled workforce; especially in the fields of programming, design, and marketing. All of the managers in the small companies deal with both project management and marketing. Additionally, 80\% (20 companies) specialize in game development processes. There are roles in many different fields of expertise in the development process. Clearly, the availability of a skilled workforce is key to the future of the gaming industry. Therefore, it is essential to implement educational policies regarding the training of people for

6 If the start of the video game industry is defined by the introduction of the first coinoperated video game (Galaxy Game, in 1971), then the industry can be considered to be 40 years old. Earlier games were not commercially used (Zackariasson and Wilson, 2012) 
game development. Such policies should be implemented in accordance with the demands of the private sector. Second and third level educational establishments should run specific gaming-related courses, such as game development, and marketing. Turkey had no game development course prior to 2009. The first postgraduate program in game technology was initiated by the Middle East Technical University (METU) in 2009.

In relation to the game types used: $45 \%$ (11 companies) develop mobile and online games. All of the surveyed companies have the ability to produce games for multiple platforms (they have the appropriate capacity and flexibility). Additionally, $84 \%$ (21 companies) believe that they can increase their production capacity without changing platform. However, only $32 \%$ (8 companies) earned money from solely developing games. This is because, along with developing games, most companies provide consultancy services and produce sophisticated digital services for other companies.

In relation to development plans: $87 \%$ (21 companies) have short-term plans (1 to 2 years). Such plans focus on developing more games, and on becoming an established company in the market. Only 45\% (11 companies) have long-term plans (6 to 10 years). Clearly, their lack of experience makes startup companies fearful of the future. Successful game development requires knowledge and experience. It is difficult for developers to develop the right game at the right time: there are lots of examples of failures. While development is the first and most crucial step, the right strategy for marketing is also crucial. Identifying the correct marketing strategies may come with experience, and developing and releasing more games to the market may give this experience. However, this process takes time. Pre-incubation centers that support gaming companies can shorten the length of time that this process takes, and can help to decrease company vulnerabilities. The long-term plans of Turkey's video gaming companies are about becoming multinational companies.

The number of gaming companies is very limited given the size of the Turkish economy and population. Most of the gaming company managers know each other, which can be beneficial. For example, the companies may exchange information about potential employees. It should be easy to establish a network among the video gaming companies in Turkey, because there are so few of them. However, interestingly, 56\% (14 companies) believe that the other companies never share their experiences, and $64 \%$ (16 companies) do not trust the other companies in the sector. Further, 60\% (15 companies) state that there is no knowledge pool that is updated continuously. Overall, the Turkish video gaming companies clearly do not generally share information with each other. 
Most of the companies (22 out of the 25 companies), believe that there is no organizational culture within the industry. The companies are reluctant to work together. Industry associations are beneficial to the overall industry, because they allow the gaming companies to determine the industry structure. Otherwise, it may be determined by people who have no knowledge of games, or of the gaming sector. A state body, the Turkish Digital Game Federation, was established in 2011, and closed down after 2 years. After 2012, two nongovernmental organizations (NGOs) - the Digital Game Developers Association $^{7}$ and Oyunder-were established.

All of the surveyed companies had published games since their establishment. In 2012, over 500 games had been developed in Turkey; in 2015, this number was approximately 1,000. Although the number of developed games is increasing, the expected economic success cannot be reached because of a lack of investment (ODTÜ- Teknokent, 2012).

It is clear that the video gaming sector has crucial problems in Turkey. But, as it is mentioned by sector leaders in SWOT, the main problem is about culture. The success of an industry comes with socially and historically embedded foundation of creative imaginary flora complemented by skilled workforce (Aoyama and Izushi, 2003). For example, Nintendo is the most important figure behind the success of Japanese video gaming sector. It was established in 1889 and published its first video game in 1983. Besides, the presence of competitive electronics industry has provided necessary labor pool and socially legitimate climate for game development culture in the country (Aoyama and Izushi, 2003). Unfortunately, in Turkey, the first game was developed in 1989 but the first and the only global success comes with Mount and Blade which was published in $2008^{8}$.

\section{Insert Coin for the Next Level? Analysis and Recommendations}

Arising from the study, the following recommendations are made for supporting the development of the Turkish video gaming industry. But, it would be better to state that the biggest game producer countries are Japan and USA have also written the history of video gaming sector. For example, Nintendo

7 The name of this Association was changed to Turkish Game Developers Association (TOGED) in 2015.

8 This game was developed by Taleworlds Company and was named as one of PC Gamer's Top 100 games of all time (https://www.taleworlds.com/en/ Content/Company ) 
from Japan which was established in 1889 published their first video game in 1983 and changed the content of sector in 1985 by dint of Mario Brothers. Such kind of success does not arise abruptly. That means it comes with intense gaming culture and education as it is in those countries (Aoyama\& Izushi, 2003). Unfortunately, the number of World-class video game produced in Turkey is 1: Mount and Blade was published in 2008. So to say, the recommendations mentioned below require more deep gaming culture within the Turkish public sphere.

Support entrepreneurial activities: In Turkey, the video gaming industry has grown exponentially, both quantitatively and qualitatively, in recent years. All of the companies in the sector are small or micro-enterprises, and most are startups. This means that improving the quantity and the quality of the entrepreneurial activities will definitely stimulate the progress of the video gaming industry. Notably, the entrepreneurial eco-system needs to be supported by specific policies.

Prepare a national strategic plan for gaming: Generally, it is nearly impossible to fully develop an industry with no state supports. Because of its considerable growth potential, Turkey's video gaming industry should be considered a priority sector, and specific policies should be established for it. All of the stakeholders with an interest in the sector should unite and should prepare a national strategic plan for gaming.

Monitor technology developments and plan for the future: Video gaming is closely related to developments in technology. Video games can be developed in any platform that the technology allows. Therefore, the policymakers and the private sector should closely monitor the developments in technology, and should prepare projections of the future. This is also true in relation to marketing strategies. The projections should also contain related $R \& D$ and innovative aspects, and national policies should be based on these projections.

Foster special educational initiatives: The major problem facing Turkey's video gaming industry is the lack of a highly skilled workforce. The industry does not just need coders and designers: the industry needs a young and skilled workforce who are acquainted with the game culture, and who has the philosophy of design and coding. The educational system has a clear role here. Particularly, there should be more courses on gaming at the university level.

Game development is not the only process in the gaming industry; marketing and project management are also important aspects. Therefore, young people should also be educated in these fields. Notably, entrepreneurship should be taught at every level of the educational system.

Develop support legislation: Turkey also needs a specific, and clearly established, a legal framework for IP rights. The ownership of a product or an 
idea has always been problematic. Further, legislation must provide a secure marketplace, by preventing black marketing, and by regulating payment systems. The rating system for games could be determined by laws. This would make it easier for video games to be accepted culturally by the general public. In other words, the negative perceptions of video games can be diminished via proper regulations.

Develop marketing and payment systems: For the gaming sector to perform well, it is important to implement specific development and product models. Especially, marketing and proper payment systems that are specific to games should be built.

Advance collaborations: To develop the video gaming industry, the participating companies should collaborate properly. NGOs are important in this respect. Such organizations can improve the trust between the stakeholders. Currently, in Turkey, there is no relationship between two video gaming NGOs. Both NGOs should take proactive roles in the market.

Acknowledge the key role played by pre-incubation centers: Pre-incubation centers should be supported by specific incentives. Young entrepreneurs should be well prepared for the challenging aspects of their sectors before entering the market. Experience, and the learning by doing, are critical in the video gaming industry. Pre-incubation centers are the best places to absorb the required experience and knowledge.

Such organizations are considered as bridging organizations that mountain interaction among various actors in the sector, such as developers, publishers, academicians, journalists, entrepreneurs...etc (Sapsed et. all, 2007) They can compensate the weaknesses of young entrepreneurs by stimulating the network among those actors and bring the success.

\subsection{University-based Pre-incubation Centers in Turkey}

The development of new research/technology-based companies has become increasingly important in today's competitive economies. Faced with this challenge, some governments are collaborating with local business leaders and entrepreneurial universities to promote the development of their regions. Such initiatives link technology, capital, and know-how. This then: leverages entrepreneurial talent, accelerates the development of new technology-based companies, and accelerates the commercialization of technology (Smilor and Gill, 1986).

A pre-incubator is a facility for very early stage start-up companies. Such companies have yet to: formulate a business plan, develop a prototype, or 
establish an entrepreneurial team. Pre-incubators lead the embryonic business to an investment and/or market-ready stage.

In a pre-incubator facility, the tenants (the startup companies) have access to managers, and to administrative, management, financial, legal, and insurance consultants, as well as to scientists, academics, and prospective customers (Peters, Rice and Sundararajan, 2004). The main role of the preincubation facility is to increase the experience and the competences of its tenant entrepreneurs.

Universities are important to technology-based companies for two reasons (Mian, 1996). First, they are perceived as a source of research (basic theoretical inquiry, and access to faculty and facilities), as well as a source of skilled employees. Second, at both state and local levels, programs (such as university business incubators) foster university-technology entrepreneurship linkages as a means of attracting, and supporting the development of, companies. In other words, the particular emphasis is given to research related, tech-based convergence between the university and the companies. By dint of close proximity of these two actors, technological innovation will be more intense (Mian, 1997).

The pre-incubator stage involves the establishment of the necessary market and product/process competences to make the startup venture appealing to the interests of business angels and venture capitalists, or to sell in the market (Todorovic and Suntornpithug, 2006). A young entrepreneur must take many important steps in the initiation phase (Baron and Shane, 2004), including: developing the idea for a new product or service; searching for the required resources (information, finance, and people); developing the business model; producing the product for the market; and selling the product in the market. All of those steps are inevitably affected by: individual factors (such as skills or motive); grouping factors (team management); the development phase (technical problems); or the marketing process (interactions with venture capitalists or customers).

The role that the incubator plays in the entrepreneurial process has developed from such requirements. Starting at the first step in the process, the incubators provide both physical and cognitive support, such as office spaces, networking opportunities, or mentorship (Baron and Shane, 2004).

All of the gaming companies currently in Turkey are startups. They are established by young entrepreneurs. Therefore, by providing special mechanisms for young entrepreneurs, the gaming industry can be substantially developed. The support mechanisms can be achieved through University-based pre-incubation centers. 
There is one pre-incubation center in Turkey that solely supports gaming game projects: the Animation Technologies and Game Development Center (ATOM). Established in 2008, ATOM has two target industries: games and animation. Its main aim is to contribute to the development of the Turkish video gaming industry via supporting entrepreneurial activities. A secondary aim is to train a highly skilled workforce. As of 2014, ten companies had graduated from ATOM, developing over 200 games for the market among them. Since then, ATOM working groups have launched over 20 games.

ATOM was the first, and only, pre-incubation center in Turkey until 2011. Now, there are approximately 20 pre-incubation centers. Most have supported some game development projects; however, they are specialized to particular areas, like the ATOM incubator.

\section{Conclusion}

Turkey has the ability to take part in the global competitive market in general, and in high technology products in particular. However, Turkey's video game industry is developing very slowly. To boost its development, crucial steps and actions should be taken. The relevant stakeholders - the public sector, the private sector, and academia - should collaborate. The support of the state and the public sector should be ensured. A national strategy should be formulated and enacted. At present, all of Turkey's video gaming companies are very young, and they lack the relevant experience. Turkey has many young and talented minds who are interested in the video gaming industry. These minds should be supported. Crucially, Turkey must find the means to develop its gaming industry so that it 'passes to the next level'.

Video game industry is relatively young and small. $45 \%$ of the firms were established after 2010 and employ fewer than 10 people. It is assumed that this kind of infancy is a hamper for Turkey. For example, there is no foreign direct investment in video gaming sector. Another serious problem is the lack of skilled workforce; notably in programming, design, and marketing. For that reason, it can be assumed that pre-incubation centers whose aim is to explore university- industry cooperation are very crucial for the development of the sector.

Most of the companies have developed mobile games as it is in the world. The market share is reached to 30 million dollars in 2016. Unfortunately, those firms have no long- term plans. Most of them have short of medium-term plan for the future. This also shows how the gaming sector is unstable in Turkey. Moreover, interestingly, 56\% (14 companies) believe that the other companies never share their experiences, and 64\% (16 companies) do not trust the other companies in the sector. Although, the economic power of sector is 
not at higher levels, the Turkish video gaming companies clearly are not keen on sharing information with each other.

This research is limited in that it was conducted in one developing country and the results are specific to the conditions in that country. However, the methodology used in the study could be used as a framework for analysis in other developing countries. Further research, particularly comparative studies, are needed to understand the scope, the impacts and the industry of video gaming. For example, customer network analysis of the companies (Shankar\& Bayus, 2003) may contribute to a clarification of the scope and the future paths of the whole industry.

Notably, there is an increasing interest from academia in video gaming. As the industry grows, it will also attract the attention of the government and other structures. This enhanced interest will lead to a further deepening in our understanding of the industry.

\section{References}

Adorno, T. (2004), The Culture Industry - Selected Essays On Mass Culture (New York: Routledge).

Aoyama, Yuko and Hiro Izushi (2003), "Hardware Gimmick or Cultural İnnovation? Technological, Cultural, And Social Foundations Of The Japanese Video Game İndustry" , Research Policy, 32(3): 423-444.

Ashton, Daniel (2011), "Upgrading the Self: Technology and the Self in The Digital Games Perpetual Innovation Economy" , The International Journal of Research into New Media Technologies, 17(3): 307-321.

Bailey, Kenneth D. (1994), Methods of Social Research. (New York: The Free Press).

Baron, Robert and Scott A. Shane (2004), Entrepreneurship: A Process Perspective (Canada: Thomson South- Western).

Bergek, Anna and Charlotte Norrman (2008), "Incubator Best Practice: A framework" , Technovation, 28 (1-2): 20-28.

Bigfish (2014) http://pressroom.bigfishgames.com/2014-01-28-Big-Fish-Celebrates-11thConsecutive-Year-of-Record-Growth (15.02.2016)

Binark, Mutlu ve Günseli Bayraktutan-Sütçü (2008). Kültür Endüstrisi Ürünü Olarak Dijital Oyun (İstanbul: Kalkedon Yayınları).

Brightman, Jonathan (2008), "Video Games Explode: Global Revenues Now On Par With Box Office, Game Daily" , http://www.gamedaily.com/articles/news/video-games-explodeglobal-revenues-now-on-par-with-box-office/?biz=1 (18.12.2015).

Causal Games Association. (2014), "Towards The Global Games Market 2017" , http://s3.amazonaws.com/CGA_Report/CCNewzooSpringReport-pages.pdf_(03.12.2015). 
Dyer-Witheford, Nick ans Zena Sharman (2005), "Political Economy Of Canada's Video and Computer Game Industry", Canadian Journal of Communication, 30 (2): 178-210.

Dymek, Mikolaj (2010), "Industrial Phantasmagoria: Subcultural Interactive Cinema Meets MassCultural Media of Simulation" http://www.diva-portal.org/smash/get/diva2:320752/ FULLTEXT01.pdf (18.12.2015).

Edery, David and Ethan Mollick (2009), Changing The Game: How Video Games Are Transforming The Future Of Business, (New Jersey: Pearson Education).

Egenfeldt-Nielsen, Simon, Jonas Heide Smith and Susana Pajares Tosca (2008), Understanding Video Games: The Essential Introduction, (New York: Routledge).

Gartner (2011), Market trends: Gaming Ecosystem 2011, Gartner Market Reports. http://www.gartner.com (13.12.2015).

Grimaldi, Rosa and Alessandro Grandi (2005), "Business Incubators and New Venture Creation: An Assessment Of Incubating Models", Technovation, 25 (2): 111-121.

Helppi, Villo Veikko. (2015), "The Agile Process For Mobile Game Development and Testing" , http://testdroid.com/tech/the-agile-process-for-mobile-game-development-and-testing (21.09.2015).

Hesmondhalgh, David (2007), The Cultural Industries, (London: Sage Publications).

Howells, Jeremy (2006), "Intermediation and The Role of Intermediaries In Innovation", Research Policy, 35, (5): 715-728.

Huizinga, Johan. (2013), Homo Ludens. (İstanbul: Ayrıntı Yayınları) (Çev. Mehmet Ali Kılıçbay).

Jethva, Khumansinh (2015), "Game Development Process - How and How Not To Proceed" , http://www.theappguruz.com/blog/game-development-process-proceed\#sthash.QLwuk QLR.dpuf (13.01.2016).

Kerr, Aphra. (2006), The Business and Culture of Digital Games. Gamework/ Gameplay, (London: Sage Publications).

Langlotz, Aoife.C.H, Marc Rhode and Clayton Whaley (2008), "Video Games Industry Overview. International Business Project Distributors" , http://holgerlanglotz.de/downloads/ BU4510_VideoGamesIndustry_LanglotzEtAl.pdf_(01.12.2015).

Malerba, Franco (2002), "Sectoral Systems of Innovation and Production", Research Policy, 31, (2): 247- 264.

McCoy, Lisa (2010), Video Games, (New York: Ferguson Publishing).

Mian, Sarfraz (1996), "The University Business Incubator: A Strategy For Developing New Research/Technology-Based Firms" , The Journal Of High Technology Management Research, 7 (2): 191-208.

Mian, Sarfraz (1997), “Assessing and Managing The University Technology Business Incubator: An Integrative Framework", Journal of Business Venturing, 12(4): 251- 285.

Neuman, William L. (2006), Social Research Methods: Qualitative and Quantitative Approaches, (6 ${ }^{\text {th }}$ Edition), (Boston: Pearson/Allyn and Bacon).

Netzley, Patricia (2015), How Do Video Games Affect Society? (San Diego: Reference Point Press).

ODTÜ-TEKNOKENT (2012), Türkiye Dijital Oyun Sektörü Raporu, (Ankara).

O'Donnell, Casey (2012), "This is Not a Software Industry", Zackariasson, Peter and Timothy L. Wilson (Der.), The Video Game Industry: Formation, Present State, and Future (New York: Routledge) 17-33. 
Peters, Lois, Marc Rice and Malavika Sundararajan (2004), "The Role of Incubators In The Entrepreneurial Process", Journal of Technology Transfer, 29 (1): 83-91.

Readman, Jeff and Andrew Grantham (2006), "Shopping For Buyers of Product Development Expertise: How Video Games Developers Stay Ahead" , European Management Journal, 24 (4): 256-269.

Sapsed, Jonathan, Andrew Grantham and Robert DeFillippi (2007), "A Bridge Over Troubled Waters: Bridging Organisations and Entrepreneurial Opportunities In Emerging Sectors", Research Policy, 36(9): 1314-1334.

Shah, Nik (2005), "The Video Game Industry: An Industry Analysis, From A VC Perspective", http://digitalstrategies.tuck.dartmouth.edu/digital/assets/images/05_shah.pdf (13.01.2015)

Shankar, Venkatesh and Bayus Barry (2003), "Network Effects and Competition: An Empirical Analysis of The Home Video Game Industry" , Strategic Management Journal, 24(4): 375-384.

Smilor, Raymond and Michael Gill (1986), The New Business Incubator: Linking Talent, Technology and Know-How, (Toronto: Lexington Books).

The Free Management E-Books Team (2013), SWOT Analysis: Strategy Skills. http://www.freemanagement-ebooks.com/dldebk-pdf/fme-swot-analysis.pdf (22.01.2016)

Todorovic, Zelimir and Nichaya Suntornpithug (2006), "University-Based Incubators - Towards A Multi-Dimensional Framework", https://opus.ipfw.edu/manage_facpres/74 (14.02.2016).

Tüdof. (2012), http://www.tudof.org/?p=1141_(15.05.2014).

Walfisz, Martin, Peter Zackariasson and Timothy Wilson (2006), "Real-Time Strategy: Evolutionary Game Development", Business Horizons, 49 (6): 487-496.

Wolf, Mark (Der) (2012), Encyclopedia of Video Games: The Culture, Technology, and Art of Gaming (Santa Barbara: Greenwood Pub).

Yılmaz, Erdal ve Kürşat Çağıltay (2005), "History Of Digital Games In Turkey, Proceedings of DiGRA 2005 Conference" http://ocw.metu.edu.tr/pluginfile.php/2328/mod_resource/ content/0/ceit706/week1/history\%20of\%20games\%20in\%20Turkey.pdf (02.07.2013).

Zackariasson, Peter and Timothy Wilson (2012), The Video Game Industry: Formation, Present State, and Future (New York: Taylor \& Francis).

www.wearesocial.sg https://www.slideshare.net/wearesocialsg/social-digital-mobile-around-theworld-january-2014 (15.02.2016).

www.esa.org http://www.theesa.com/wp-content/uploads/2017/04/EF2017_FinalDigital.pdf (19.04.2016)

www.gamasutra.com, http://gamaphp.gamasutra.com/view/news/217618/Take_Two_reports_ record_revenue_on_back_of_Grand_Theft_Auto_V.php (20.03.2016).

https://www.taleworlds.com/en/Content/Company (22.04.2016)

http://www.ecchigames.com/video-game-platforms.html_(10.08.2016).

http://www.theguardian.com/technology/2014/jun/04/sony-psp-handheld-nintendo (20.03.2016).

https://newzoo.com/insights/articles/global-games-market-will-reach-102-9-billion-2017-2/ (20.03.2016).

http://www.euromonitor.com/video-games-in-turkey/report (20.03.2016). 